\title{
Use of Food Services by Consumers in the SARS-CoV-2 Pandemic. How the Eating Habits of Consumers Changed in View of the New Disease Risk Factors?
}

\author{
Ewa Czarniecka-Skubina ${ }^{1, *(\mathbb{D})}$, Marlena Pielak ${ }^{1}$, Piotr Sałek ${ }^{1}\left(\mathbb{D}\right.$, Artur Głuchowski $^{1}{ }^{(\mathbb{D})}$, \\ Joanna Kobus-Cisowska ${ }^{2}$ (D) and Tomasz Owczarek ${ }^{3}$ (D)
}

1 Department of Food Gastronomy and Food Hygiene, Institute of Human Nutrition Sciences, Warsaw University of Life Sciences (WULS), Str. Nowoursynowska 166, 02-787 Warsaw, Poland; marlena_pielak@sggw.edu.pl (M.P.); piotr_salek@sggw.edu.pl (P.S.); artur_gluchowski@sggw.edu.pl (A.G.)

2 Department of Gastronomy Sciences and Functional Foods, Faculty of Food Science and Nutrition, Poznan University of Life Sciences, Wojska Polskiego 28, 60-637 Poznań, Poland; joanna.kobus-cisowska@up.poznan.pl

3 Department of Management and Economics, Gdynia Maritime University, Str. Morska 81-87, 81-225 Gdynia, Poland; t.owczarek@wzjn.umg.edu.pl

* Correspondence: ewa_czarniecka_skubina@sggw.edu.pl; Tel.: +48-(22)-5937063

\section{check for} updates

Citation: Czarniecka-Skubina, E.; Pielak, M.; Sałek, P.; Głuchowski, A.; Kobus-Cisowska, J.; Owczarek, T. Use of Food Services by Consumers in the SARS-CoV-2 Pandemic. How the Eating Habits of Consumers Changed in View of the New Disease Risk Factors? Nutrients 2021, 13, 2760. https://doi.org/10.3390/nu13082760

Academic Editor: Emma Ruiz Moreno

Received: 20 July 2021

Accepted: 7 August 2021

Published: 11 August 2021

Publisher's Note: MDPI stays neutral with regard to jurisdictional claims in published maps and institutional affiliations.

Copyright: (c) 2021 by the authors. Licensee MDPI, Basel, Switzerland. This article is an open access article distributed under the terms and conditions of the Creative Commons Attribution (CC BY) license (https:/ / creativecommons.org/licenses/by/ $4.0 /)$.

\begin{abstract}
The SARS-CoV-2 pandemic in 2020-2021 changed the eating habits of people around the world. The aim of this study is to understand the effects of COVID-19 on changing consumers' eating habits, including their concerns about food service nutrition in case of new disease risk factors. The survey conducted using the computer-assisted web-based interviewing method on a group of 1021 adult respondents in Poland. We collected information about consumer choices and habits related to use of food services during the pandemic. This research found that COVID-19 had an impact on consumers' use of food services, both on-site and take-away. Using cluster analysis, we identified five main groups of food service consumers. It was found that almost half of the respondent group did not change their diet during the pandemic, 20\% of respondents changed their diet to a positive one, and $20 \%$ to a diet that was negative. For respondents the most important forms of protection against COVID-19 in catering establishments were hand disinfection (70.3\%), table disinfection $(70.4 \%)$, wearing of masks and visors by staff $(68.2 \%)$, and the possibility of cashless payments $(64.6 \%)$. Based on cluster analysis (eight consumer clusters), we stated that majority of respondents did not see any threats to using catering service during the pandemic. Only a small group $(8.1 \%)$ of respondents were afraid of the possibility of getting sick with COVID-19. This study presented the effects of COVID-19 on consumer eating behavior in catering and their concerns with food services uses. Discovering consumer concerns can reduce risk, increase food safety and improve eating habits.
\end{abstract}

Keywords: food service; consumer; eating habits; SARS-CoV-2; Poles

\section{Introduction}

COVID-19 disease, caused by SARS-CoV-2, was first reported in December 2019 in Wuhan, China. Symptoms of the disease develop from 2 to 14 days after exposure, causing fever, cough, and shortness of breath, sore throat and muscles, and loss of taste and smell $[1,2]$. It may also be asymptomatic, have mild or severe symptoms leading to hospitalization and even death in patients with comorbidities [3-6]. Person-to-person transmission of the virus occurs at local, regional, national, and international levels. The virus can make others sick and contaminate the environment, including food products [7]. The virus spreads rapidly around the world, which is why in March 2020 a global pandemic was announced. Countries (e.g., China, South Korea, India) where the first cases of the disease were confirmed began to implement a rigorous hygiene regime and nationwide prevention 
measures such as disinfection, personal protective equipment, complete restriction on all international and domestic travel, social isolation, and suspension of many services and quarantine. Companies that were essential to society or offering basic necessities, such as grocery stores, remained open to consumers while companies and institutions that gather a lot of people, such as restaurants, hotels, and various types of schools, were temporarily closed [8,9], except take-away and home deliveries. About 4 billion people have been forced by the pandemic to either quarantine or isolate themselves at home [10-12]. The COVID-19 pandemic has severely impacted the global economy with huge effects on all business sectors, including tourism, food service, cultural events, and trade fairs [13].

In March 2020, the gastronomy and hotel industry, shopping malls, schools, and universities were all closed in Poland, introducing a remote education system and restrictions applied to public meetings. For most Poles, the initial order to stay at home was for six weeks. For selected groups, this period was longer and covered more than one year $[14,15]$. This has led to a noticeable decrease in "social consumption". The gastronomy and hotel industry suffered the most because of the introduced restrictions. The average decrease in demand for goods and services in the catering and accommodation industry during pandemic (April 2020-February 2021) dropped -41.4\% [16,17]. The Polish Gastronomy Chamber of Commerce estimates that in April-May 2021, 15,000 business have been bankrupted due to the lockdown of catering establishments (i.e., about $20 \%$ of all facilities). The pandemic stopped the previous clear trend of increasing household expenditure on food services in Poland [18]. The effects of the current SARS-CoV-2 will be the most clear and durable in the tourism and hospitality sectors, as habits related to traveling and eating changed [19]. The pandemic resulted in huge revenue losses in the catering industry, accounting for up to $80 \%$ of revenue, and many restaurants were closed, with even fast-food sales in the U.S. and China decreasing [20-23]. Similar changes were found in Europe [24].

Predicting trends, analyzing customer needs and consumer behavior, by studying the factors that influence consumer choice and restaurant demand, is particularly important for the catering industry, due to the instability of related products and services, and may be helpful in restaurant management [25]. However, the COVID-19 pandemic differs from other food organization crises because of its severity, devastating effects, evolving nature, and very limited organizations' ability to control the situation. Due to the nature of the COVID-19 crisis, the need for strategic action and searching for new channels for the provision of food and catering services is a key aspect for catering organizations.

Discovering consumer concerns can reduce risk, increase safety, and improve eating habits. The aim of this study is to understand the effects of COVID-19 on changing consumers' eating habits, including their concerns about food service nutrition in case of new disease risk factors. The second goal of this study is to identify, describe, and compare consumer segments based on differences in individual food choices, concerns, and eating habits in catering establishments during the COVID-19 pandemic.

\section{Literature Review}

Human disease pandemics are influencing consumer psychology and consumer behavior and habits. The international crisis caused by the spread of the new coronavirus has brought food safety concerns to the fore. Risk perception plays a key role in determining healthy behavior [26]. Anxiety caused by the food shortages in grocery stores triggered panic in customer, who focused on buying semi-finished products and food products to prepare at home [27]. Restrictions on restaurants were one of the reasons for the excess accumulation of products by consumers.

Quarantines and restrictions related to the COVID-19 pandemic can be considered highly stressful events that affect eating patterns. The transition period associated with a pandemic situation, therefore, has the potential to change eating habits, forcing most people to stay at home, sometimes in home-offices, for long periods, often with unlimited access to food in home and less physical activity [28]. Staying at home for a long time 
may favor snacking between meals, eating 'junk food' snacks, and drinking alcohol, and it may affect the consumer's individual choices about cooking at home, buying ready-to-eat products, as well as using takeaway food services [28-36]. The perceived risk of COVID-19 and guidelines for minimizing personal contact might have been discouraging consumers from using gastronomy during the pandemic $[37,38]$.

In the literature on the functioning of gastronomy and consumer behavior before the SARS-CoV-2 pandemic, numerous studies examine factors influencing the demand for catering establishments, such as: food quality [39], hygiene and food safety [40], price [41], quality of services [42], location [43], and online consumer feedback [44]. Crise such as the pandemic 2020/2021, constitute a unique, critical force among the mentioned factors and affect consumer behavior and the functioning of the foodservice industry, creating serious consequences for the industry. Before the COVID-19 pandemic, only a few empirical studies [45-51] looked at the impact of crises on consumer food choices, demand in restaurants and managing food production during crise caused by epidemic diseases, such as severe acute respiratory syndrome (SARS) and the avian flu. Few studies [52] concerned the reactions of consumers to the crises. Most of the research looked at the impact of food safety and economic crises on the foodservice industry. However, there was a lack of empirical studies that took into account the impact of the epidemic crisis on the demand and operation of restaurants [53] and on consumer behavior related to nutrition in gastronomy. Some studies indicate the socio-economic effects of pandemic on individual aspects of the world economy [54-58]. Many previous research papers [14,28,32-35,53,59-71] conducted during the pandemic were devoted to the impact of the situation on eating habits, adherence to a the Mediterranean diet in Italy, a potential protective role of micronutrients, phytochemicals and Mediterranean diet against COVID-19, the potential to increase the stress level and its associated impact on the pre-existing diseases such as diabetes and changes in the diet of people or the impact of nutritional status in patients with COVID-19 and those who have had the disease [61,72-74]. So far, only a few studies $[31,63]$ have analyzed the impact of the pandemic on use of food services.

We are supplementing the literature by examining the effects of COVID-19 on consumer eating habits in catering and their possible concerns in the light of new disease risk factors.

\section{Materials and Methods}

\subsection{Study Design}

This paper was designed as a study with a convenience sampling. The respondents completed the questionnaire online. A link to the questionnaire in a Polish language Google Forms format was sent via Facebook, WhatsApp, e-mail, and students' forum. A questionnaire provided on a webpage increases the sense of anonymity and gives an opportunity to participate in the study at a time convenient for the respondent, which was very useful during the COVID-19 pandemic.

The questionnaire was designed based on previous research related to eating habits in catering establishments $[38,75,76]$. The questionnaire was checked by means of a pilot study with 25 people. All problems were identified, and the questionnaire was completed and amended. It was estimated by the pilot test that completing the form would take each participant around 10-15 min.

The study protocol was approved by the Ethics Committee of the Institute of Human Nutrition Sciences of the Warsaw University of Life Sciences (no. 12/2021).

\subsection{Questionnaire}

The questionnaire structure for this study is presented in Table A1 (Appendix A). It consists of two parts, with the first part containing 24 questions relating to the impact of the pandemic on the use of food services by Polish consumers. The questions covered habits associated with the use of catering services before (four questions) and during the pandemic (twenty questions), and anxiety about using these services during this difficult time. The 
questions also concerned the eating habits of respondents, such as preparing meals at home, choosing the type of catering establishments and type of meals in gastronomy, the impact of the pandemic on their diet (limit or increases different food products). Questions were also related to consumers' concerns about food service use during the pandemic. Do they limit use of food services? What is their opinion on protective practices utilization in catering establishments during a pandemic? The second part of the questionnaire included five questions related to respondent's sociodemographic details (gender, age, education, dwelling place, financial situation).

\subsection{Data Collection}

The computer-assisted web-based interviewing (CAWI) method was used to collect all data [77-79]. The survey was conducted on a group of 1021 adult respondents in Poland. Inclusion criteria for respondents of the study were as follows:

1. Each respondent between 18 to 65 years old who agreed to participate in the survey was invited to complete the questionnaire.

2. Anyone who used catering establishments.

The respondents were free to participate in the research.

\subsection{Data Analysis}

The statistical analysis of the results was performed using Statistica software (version 13.3 PL; StatSoft Inc., Krakow, Poland).

The Kruskal-Wallis $(\mathrm{K}-\mathrm{W})$ test was used in the study to assess the influence of factors describing the population on the examined features. In situations where there are only two samples in the analysis, the K-W test was replaced by the U-Mann-Whitney test $[80,81]$. Significance of differences between the values was determined at a significance level of $p<0.05$.

Cluster analysis was used to classify food service consumers and their concerns about the COVID-19 pandemic. The purpose of the analysis is to create groups of respondents with a homogeneous approach to the use of catering services during the COVID-19 epidemic and homogeneous concerns regarding the use of these services. The vast majority of variables are on the ordinal scale, with a few variables on the nominal scale and two on the ratio scale. The measure of similarity used in cluster analysis is the distance in a multidimensional coordinate system. Due to the qualitative nature of the variables, the analysis used the percentage discrepancy as a measure of distance. It is the quotient of the number of dimensions with inconsistent values and the number of all dimensions. When studying distances between clusters of multiple elements, it is also necessary to establish a method for calculating the distances of clusters. The study decided to use the complete linkage clustering method, also known as the farthest neighborhood method. The distance between clusters is the distance of the farthest elements of both clusters [82-87].

At the beginning of the analysis, the agglomeration method was used to detect highly correlated variables (questions), i.e., variables that carry the same information, and to reduce their number. Then, using a reduced number of variables, the respondents were divided into homogeneous groups. In the first step, the optimal number of clusters was determined by the method of agglomeration. In the second one, the k-means method was used to finally divide all consumers into homogeneous clusters. Due to the difficult interpretation of the obtained results, it was decided to create the smallest possible number of clusters ensuring a clear segmentation of the community. For each of the clusters, the medians were calculated and used to identify the characteristics of the groups.

\section{Results}

\subsection{Characteristics of Respondents}

The characteristics of the respondents are presented in Table 1. The study involved mainly women, with secondary or higher education, living in different types of dwelling 
places. The respondents were in the range of 18-65 years old, had access to a computer and the Internet, and had computer literacy skills.

Table 1. Characteristics of the surveyed sample of respondents.

\begin{tabular}{|c|c|c|c|}
\hline \multirow{2}{*}{$\begin{array}{c}\text { Population } \\
\text { Features }\end{array}$} & \multirow{2}{*}{ Group } & \multicolumn{2}{|c|}{ Respondents } \\
\hline & & Number $(n)$ & Percentage $(\%)$ \\
\hline Total & - & 1021 & 100.0 \\
\hline \multirow{2}{*}{ Gender } & women & 658 & 64.4 \\
\hline & men & 363 & 35.6 \\
\hline \multirow{4}{*}{ Age } & $18-25$ years old & 364 & 35.7 \\
\hline & $26-40$ years old & 398 & 39.0 \\
\hline & $41-55$ years old & 228 & 22.3 \\
\hline & $>56$ years old & 31 & 3.0 \\
\hline \multirow{3}{*}{ Education } & vocational or primary school & 152 & 14.9 \\
\hline & secondary school & 485 & 47.5 \\
\hline & higher education (university) & 384 & 37.6 \\
\hline \multirow{5}{*}{ Dwelling place } & city over 250,000 inhabitants & & \\
\hline & city between $50,000-250,000$ & 543 & 53.2 \\
\hline & inhabitants) & 131 & 12.8 \\
\hline & city between $10,000-50,000$ inhabitants & 164 & 16.1 \\
\hline & $\begin{array}{c}\text { city below } 10,000 \text { inhabitants and } \\
\text { village }\end{array}$ & 183 & 17.9 \\
\hline \multirow{4}{*}{$\begin{array}{c}\text { Financial } \\
\text { situation in own } \\
\text { opinion }\end{array}$} & very good & 163 & 16.0 \\
\hline & good & 541 & 53.0 \\
\hline & not good not bad & 261 & 25.5 \\
\hline & bad & 56 & 5.5 \\
\hline
\end{tabular}

\subsection{Diet and Eating Habits Connected to Catering Services before and during a Pandemic}

Most respondents (95\%) used food services regularly prior to the pandemic, usually once a month (median 4 ), once every two-three months (median 3), or rarely (median 2 ). These were various types of catering establishments (Table 2). They most frequently used the services of pizzerias, restaurants, fast food establishments, cafes and bars (Table 2).

Table 2. Using catering establishments, frequency of use before pandemic time.

\begin{tabular}{|c|c|c|c|c|c|c|c|c|}
\hline \multirow{2}{*}{ Type } & \multicolumn{2}{|c|}{ Response } & \multirow{2}{*}{$\begin{array}{c}\begin{array}{c}\text { Frequency } \\
\text { of Use }\end{array} \\
\text { Median }\end{array}$} & \multicolumn{5}{|c|}{$p$-Value * } \\
\hline & Number & Percentage & & Gender & Age & Education & $\begin{array}{c}\text { Dwelling } \\
\text { Place }\end{array}$ & $\begin{array}{c}\text { Financial } \\
\text { Status }\end{array}$ \\
\hline 1. Canteens & 759 & 74.3 & 2 & 0.0000 & NS & 0.0109 & 0.0000 & 0.0078 \\
\hline 2. Fast food & 900 & 88.1 & 4 & 0.0007 & 0.0000 & 0.0000 & NS & NS \\
\hline 3. Restaurants & 913 & 89.4 & 4 & NS & 0.0000 & 0.0000 & 0.0000 & 0.0000 \\
\hline 4. Pizzerias & 943 & 92.4 & 4 & 0.0102 & 0.0000 & 0.0002 & NS & 0.0005 \\
\hline 5. Kebab house & 853 & 83.5 & 3 & 0.0000 & 0.0000 & 0.0005 & NS & NS \\
\hline $\begin{array}{l}\text { 6. Asian food } \\
\text { restaurants }\end{array}$ & 823 & 80.6 & 3 & 0.0000 & 0.0000 & 0.0233 & 0.0000 & 0.0007 \\
\hline 7. Café and bars & 868 & 85.0 & 4 & NS & 0.0006 & 0.0000 & 0.0002 & 0.0001 \\
\hline 8. Roadside catering & 804 & 78.7 & 2 & 0.0067 & 0.0052 & NS & NS & 0.0133 \\
\hline 9. Street food outlets & 717 & 70.2 & 2 & 0.0119 & 0.0000 & NS & NS & 0.0044 \\
\hline
\end{tabular}

* significance values in the ANOVA K-W tests, NS-not significant, $p<0.05 ; * *(8)$ : every day; (7): three or four times a week; (6): once a week; (5): two-three times a month; (4): once a month; (3): once 2-3 months; (2) rarely than once 2-3 month; (1) did not use. 
For statistically significant results of the K-W test, a post-hoc analysis was performed using the Dunn test. Its results indicate groups of people using gastronomy with different frequency.

Various types of catering establishments were used significantly more often by men and people aged 26-40. People aged 41-55 used canteens significantly more often. The use of catering establishments also depended on the education of the respondents. People with primary and vocational education chose fast food establishments significantly more often. People with secondary education usually chose pizzerias, kebab establishments, cafes, and bars. On the other hand, people with higher education chose canteens and restaurants significantly more often. The choice of catering establishments was also influenced by the financial status and dwelling place of respondents. People with very good income and living in the city with over 250,000 inhabitants used gastronomy services more often (Table 2).

A significant percentage of respondents (96.6\%) prepared their own meals at home. The frequency of preparing meals by the respondents before the pandemic and during the pandemic did not change and was on average several times a week. Nearly $50 \%$ of respondents did not change their diet during the pandemic. About $20 \%$ of respondents started to take care of their diet and limit their consumption of sweets. This was indicated significantly more often by younger people $(p=0.0014)$ and people with secondary education $(p=0.01)$. About $11.5-13.5 \%$ of respondents were limiting consumption of meat, started to pay attention to the energy value of meals, with $6.4 \%$ limiting consumption of fats. Meat in the diet was significantly more often restricted by people living in cities of more than 250,000 inhabitants $(p=0.0305)$, with a very good financial situation $(p=0.0440)$, while people aged $18-25(p=0.0000)$, with secondary education $(p=0.0001)$ paid attention to the energy value of the diet significantly more often. About $20 \%$ of the respondents drank more alcohol, ate more sweets, and didn't pay attention to the energy value of meals, and $10.9 \%$ of people consumed more fats and carbs. Alcohol consumption increased significantly more often among men $(p=0.0059)$, people with secondary education $(p=0.0034)$, those living in large cities $(p=0.0003)$, with a very good financial situation $(p=0.0131)$. On the other hand, people with a bad financial situation significantly more often did not pay attention to the caloric content of meals $(p=0.0023)$. A small percentage of respondents ate more vegan dishes $(0.4 \%)$.

\subsection{Use of Catering Services during a Pandemic by Respondents}

Before the pandemic, nearly $90 \%$ of respondents regularly used gastronomy services both on-site, take-away (or drive-thru) (median 5), as well as ordering for home or work delivery (median 4) (Table 3). During the pandemic, 61.3\% of respondents limited leaving home and kept it to a minimum. Quite a significant percentage of respondents $(87.9 \%)$ used food services during the pandemic. However, a limitation in the use of catering services on the premises, and take-away (median 4 ) was observed in favor of home and work deliveries, medians 5 (Table 3 ).

The results of Dunn's test of multiple comparisons that followed a K-W test revealed more detailed information of the effect of socio-economic variables on food services use.

The respondents were asked if they plan return to food consumption on site in a catering establishment after the pandemic, and indicated that they already do it while maintaining hygiene and distance (31.6\%) or used it when there was a possibility (30.8\%). That was significantly more often reported by people in aged $26-40$, with higher education, living in cities with over 250,000 residents, and with a very good financial situation. Only $6.4 \%$ of the respondents indicated that they would return to gastronomy only when the pandemic is over. Approximately $31.2 \%$ had no opinion on this subject, which was probably caused by the dynamically changing situation in terms of the number of infections. 
Table 3. Using catering establishments and frequency of use by respondents before and during pandemic.

\begin{tabular}{|c|c|c|c|c|c|c|c|c|}
\hline \multirow{2}{*}{ Place } & \multicolumn{2}{|c|}{ Response } & \multirow{2}{*}{$\begin{array}{c}\begin{array}{c}\text { Frequency of } \\
\text { Use }\end{array} \\
\text { Median }\end{array}$} & \multicolumn{5}{|c|}{$p$-Value * } \\
\hline & Number & Percentage & & Gender & Age & Education & $\begin{array}{l}\text { Dwelling } \\
\text { Place }\end{array}$ & $\begin{array}{c}\text { Financial } \\
\text { Status }\end{array}$ \\
\hline \multicolumn{9}{|l|}{ Before the pandemic } \\
\hline On-site/dine in & 938 & 91.9 & 5 & NS & 0.0001 & 0.0002 & NS & 0.0158 \\
\hline Take away/drive thru & 887 & 86.9 & 5 & 0.0374 & 0.0002 & 0.0344 & NS & 0.0391 \\
\hline Home/work delivery & 843 & 82.6 & 4 & 0.0000 & 0.0000 & 0.0002 & 0.0000 & 0.0013 \\
\hline \multicolumn{9}{|l|}{ During the pandemic } \\
\hline On-site/dine in & 728 & 71.3 & 4 & 0.0005 & 0.0002 & 0.0000 & 0.0000 & 0.0000 \\
\hline Take away/drive thru & 771 & 75.5 & 4 & 0.0001 & 0.0000 & 0.0085 & 0.0014 & 0.0005 \\
\hline Home/work delivery & 810 & 79.3 & 5 & 0.0664 & 0.0036 & 0.0008 & 0.0000 & 0.0000 \\
\hline
\end{tabular}

* time significance values in the ANOVA K-W tests; NS-no significant, $p<0.05$; ${ }^{* *}(8)$ : every day; (7): three or four times a week; (6): once a week; (5): two-three times a month; (4): once a month; (3): once a 2-3 months; (2) rarely than once a 2-3 month; (1) Did not use.

The most common reasons for limiting the use of gastronomy services were working or learning online, lower frequency of business meetings ( $40.5 \%$ of indications), limiting tourist activity such as traveling, sightseeing, or use of hotels $(37.5 \%)$, limiting shopping in malls $(37.2 \%)$, restricting attendance at cultural events such as cinema, theater, and concerts $(32 \%)$, fear of COVID-19 (30.4\%), financial considerations (26.7\%), and the limitation of people's movements at petrol stations, airports, railway stations $(22.8 \%)$, discomfort related to the restrictions in the catering sector $(21.8 \%)$, restrictions at special events $(17.4 \%)$, and other $(0.9 \%)$.

\subsection{Factors of the Choice of Gastronomic Services by Respondents during a Pandemic}

The most important factors in the choice of food services by respondents during the pandemic were: the quality of meals, price, delivery options and order fulfillment execution time (median 6, Table 4). A significant percentage of respondents (59.9\%) reported that the quality of food services during the pandemic was provided at the highest level. About one third (33.6\%) of respondents rather agreed with this statement, $20.2 \%$ agreed and $6.1 \%$ strongly agreed. The opposite opinion was held by $10.5 \%$ of the respondents, and $23.4 \%$ did not have an opinion on this topic.

Table 4. Factors of catering establishments choice by respondents during a pandemic.

\begin{tabular}{|c|c|c|c|c|c|c|}
\hline \multirow{2}{*}{ Factors of Choice } & \multirow{2}{*}{$\frac{\text { Response }^{* *}}{\text { Median }}$} & \multicolumn{5}{|c|}{$p$-Value * } \\
\hline & & Gender & Age & Education & Dwelling Place & Financial Status \\
\hline Quality of dishes & 6 & 0.0788 & 0.0000 & 0.0000 & 0.0002 & 0.0000 \\
\hline Price & 6 & NS & 0.0001 & 0.0001 & 0.0016 & NS \\
\hline Brand & 4 & NS & 0.0429 & 0.0081 & NS & 0.0001 \\
\hline $\begin{array}{c}\text { Opinion and popularity of } \\
\text { the premises }\end{array}$ & 5 & NS & 0.0000 & 0.0000 & 0.0313 & NS \\
\hline Sense of safety & 5 & NS & NS & 0.0046 & NS & NS \\
\hline Nutritional value & 4 & 0.0077 & 0.0129 & NS & NS & 0.0077 \\
\hline $\begin{array}{l}\text { Possibility to order meals: } \\
\text { vegan, low fat, gluten free }\end{array}$ & 4 & 0.0001 & NS & NS & NS & NS \\
\hline Assurance hygienic practices & 5 & NS & NS & 0.0031 & NS & NS \\
\hline Order fulfillment time & 6 & NS & 0.0133 & 0.0010 & NS & NS \\
\hline Possibility of delivery & 6 & NS & 0.0005 & 0.0002 & NS & NS \\
\hline
\end{tabular}

${ }^{*}$ significance values in the ANOVA K-W tests, NS-no significant; ${ }^{* *}$ Scale: (1): strongly disagree; (2): disagree; (3): somewhat disagree;

(4): neither agree nor disagree; (5) somewhat agree; (6) agree: (7) strongly agree. 
During social isolation, the respondents most often ordered pizza (77.3\% of responses), fast-food meals (52.5\%), Asian cuisine meals (42.4\%), sushi (37.6\%), American cuisine meals (35.5\%), promotional meals (31.9\%), traditional lunch meals (28\%), and pasta (25.6\%). Meals such as salads and fit dishes, street food, Indian cuisine, special diet meals (vegan, gluten meals, light meals), and desserts were ordered rarely (12.6-17.7\% of indications). A few people mentioned kebab, hummus, dumplings, Georgian or Turkish dishes, as well as 'box diet'.

Special promotions, such as special discount coupons $(20.5 \%)$, discounts $(22.4 \%)$, and additional bonuses, such as two for the price of one (33.3\%), encouraged respondents to use food services. However, nearly $50 \%$ of the respondents did not report using any promotions in food services during the pandemic.

The results of the K-W test (Table 4) indicate that gender, dwelling place and financial status rarely significantly affect the factors of catering establishments choice. The possibility of ordering special dishes, assurance hygienic practices and sense of safety are not differentiated by the analyzed factors.

Based on Dunn's post-hoc tests, we can conclude that mainly the behaviors of respondents aged 25-40 and 55+ differed from the others. They chose restaurants less often because of the quality of the served dishes and more often than others because of the price, popularity of the restaurant and the possibility of delivery. The oldest people, on the other hand, more often followed the brand and less often the nutritional value of the dishes. Consumer education also often differentiates the factors of choosing eateries. People with primary and vocational education are less likely to pay attention to the price, sense of safety, assurance hygienic practices and the possibility of delivering the ordered dishes. Respondents with higher education more often pay attention to the quality of dishes, the brand and opinions about a restaurant. Consumers with secondary education more often than others pay attention to the time of order fulfillment. Generally, the higher the education, the more factors are important in choosing a gastronomic establishment. Gender differentiates the choices of dining establishments in a few cases. Women attach more importance to the nutritional value of dishes and the possibility of choosing vegan and vegetarian dishes, while men are more concerned with the quality of the dishes.

In order to divide consumers into homogeneous groups using catering services during the epidemic, the agglomeration method of cluster analysis was used. Initially, 63 variables were included in the analysis. As a result of the agglomeration, groups of strongly related variables were created and all of them were removed, leaving one variable. As a result of this operation, 16 unique variables remained in the analysis. Using collected variables, an agglomeration of cases (respondents) was carried out. The aim was to create fewer homogeneous groups of respondents. It was decided to create 5 clusters:

Cluster 1: Homemade food enthusiasts;

Cluster 2: Non-regular gastronomy customers;

Cluster 3: Occasional customers of gastronomy;

Cluster 4: Moderate enthusiasts of gastronomy;

Cluster 5: Gastronomy enthusiasts.

In the extended analysis, all observations were divided into 5 groups using the kmeans cluster analysis method. Medians calculated for each variable (after reduction) and for each cluster were used to describe consumer behavior in individual clusters (Figure 1). 


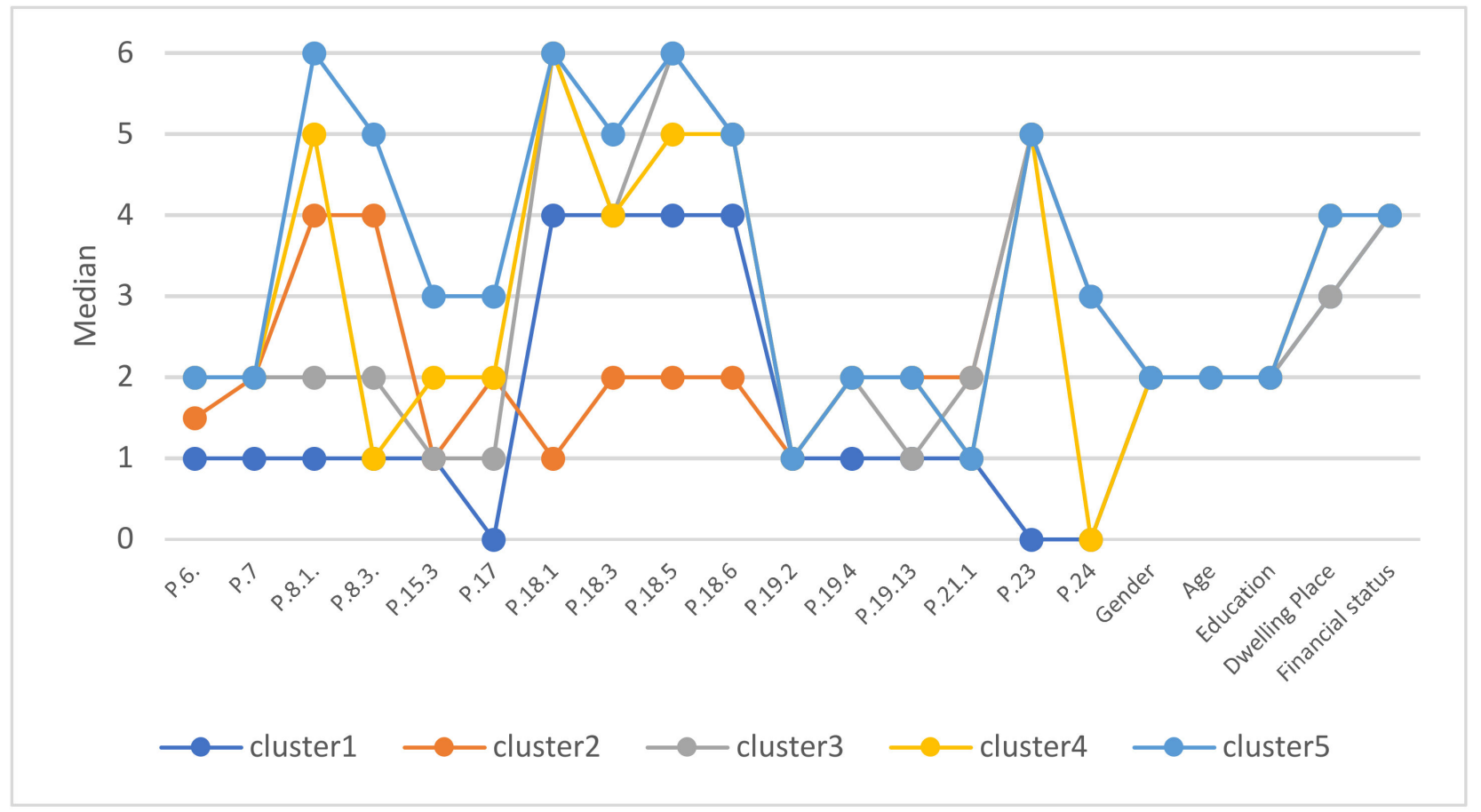

Figure 1. Medians of selected characteristics for observation in various clusters due to the behavior of consumers using catering services.

The first group of consumers (cluster 1-"Homemade food enthusiasts") are people who did not use catering services during the pandemic $(n=101,9.9 \%$ of respondents). These people also did not use often these services before the pandemic and do not plan to use them after the pandemic ends. The average representative of this group is a young woman (25-40 years old) with secondary education, living in a medium-sized city (50-250 thousand inhabitants), with a good financial situation. The lack of differentiation of the average consumer in clusters may indicate that the factors describing the respondents did not have a significant impact on their behavior as consumers of catering services.

Cluster 2 ("Non-regular gastronomy customers") are people who use catering services ( $n=94,9.2 \%$ of respondents), but as a result of the pandemic, use them less often. Occasionally, they order food from eateries, sometimes through specialized portals. They don't pay much attention to what they buy. They are generally satisfied with the services provided and plan to use them with appropriate precautions. These are the customers who use these services when they are unable to prepare their own meals.

Cluster 3 ("Occasional customers of gastronomy") are consumers who use catering services very sporadically, rather conservatively, and not using specialized portals $(n=220$, $21.5 \%$ of respondents). They attach great importance to all aspects of the catering service but are generally very satisfied with the services provided. They plan to return to gastronomy after the danger of the pandemic has ceased. These are occasional customers celebrating with purchased meals.

Cluster 4 ("Moderate enthusiasts of gastronomy") consists of people who have reduced their use of catering services as a result of the pandemic, who order food moderately often but do not plan to eat at the premises even after the pandemic has stopped $(n=223,21.8 \%$ of respondents). They attach great importance to all the features of the catering service, especially its quality and price. They order different dishes from time to time, depending on their mood or the food's availability. They order food from catering establishments when they want a little variation in their daily diet.

Cluster 5 ("Gastronomy enthusiasts") is a group of people who, despite the fact that they limited the use of catering services as a result of a pandemic, often order take-out food 
and often, if possible, use the services at the establishments ( $n=383,37.5 \%$ of respondents). They quite often use the help of specialized gastronomic portals and pay for orders using electronic payments. They value the high quality and safety of catering services, but do not neglect its other aspects as well. They do not have specific tastes regarding their selected dishes, but rather avoid traditional cuisine. They are generally satisfied with these services and use them consistently, declaring safety as an important behavior.

\subsection{Respondents' Sense of Security When Using Catering Services during a Pandemic}

During the pandemic, both in the period of no possibility to consume in catering establishments and after the opening them, the respondents indicated that their use of food services sometimes raised anxiety (median 2-yes). After the opening of catering establishments, this was indicated significantly more often by people in large cities over 250,000 inhabitants $(p=0.0011)$ and people with higher education $(p=0.0281)$. The smallest number of respondents $(58.3 \%)$ reported that they felt safe on the premises. Choosing takeaway option $(69.3 \%)$, ordering home or work delivery $(72.2 \%)$, collecting ordered meals from catering establishments themselves was according to respondents safer. The most important forms of protection customers who consumed foods on the premises during the pandemic were considered: hand disinfection (70.3\% of indications), disinfection of tables $(70.4 \%)$, wearing of masks and the visors by staff $(68.2 \%)$ and the possibility of cashless payments (Table 5). The same forms were indicated during the purchase of take away or drive-thru, as well as home and work deliveries.

Table 5. Protection used in catering establishments against the spread of the virus *.

\begin{tabular}{ccccccccc}
\hline \multirow{2}{*}{ Protection Forms } & \multicolumn{2}{c}{ Dine-in } & \multicolumn{2}{c}{$\begin{array}{c}\text { Take } \\
\text { Away/Drive-thru }\end{array}$} & \multicolumn{2}{c}{ Home/Work Delivery } & Security Validity * \\
\cline { 2 - 9 } & $\mathbf{n}$ & $\mathbf{\%}$ & $\mathbf{n}$ & $\mathbf{\%}$ & $\mathbf{n}$ & \% & Average & Median \\
\hline Distance of 2 m from other people & 604 & 59.2 & 403 & 39.5 & 415 & 40.6 & 3.7 & 4 \\
Plexiglass partitions & 429 & 42.0 & 323 & 31.6 & 59 & 5.8 & 3.4 & 3 \\
Hand disinfection & 718 & 70.3 & 380 & 37.2 & 231 & 22.6 & 4.3 & 5 \\
Staff wearing disposable gloves & 577 & 56.5 & 544 & 53.3 & 442 & 43.3 & 4.0 & 4 \\
Staff wearing protective masks or visors & 696 & 68.2 & 596 & 58.4 & 617 & 60.4 & 4.3 & 5 \\
Disinfection of tables & 719 & 70.4 & 117 & 11.5 & 76 & 7.4 & 4.3 & 5 \\
Cashless payment availability & 660 & 64.6 & 611 & 59.8 & 640 & 62.7 & 4.1 & 4 \\
Disinfection of payment terminals & 359 & 35.2 & 257 & 25.3 & 174 & 17.0 & 3.7 & 4 \\
Other non-compliances & 71 & 7.0 & 23 & 2.3 & 33 & 3.2 & - \\
\hline
\end{tabular}

* (5): very important; (4): important; (3): neutral; (2): low importance; (1): not at all important.

Many respondents stated that in numerous establishments no safeguards were introduced. The proper distance was not kept, there were too many people on the premises, masks were not used by personnel and customers or were worn incorrectly, no gloves were used, no hand disinfection was used, and finally the payment terminals were not disinfected. Most comments were made about the disinfection of the tables. According to the respondents, in many places the tables were not disinfected at all or inadequately, or even only a misleading or false note about disinfection was on the table.

\subsection{Consumer Segmentation Due to Concerns about Food Service Use during a Pandemic}

For the cluster analysis the concerns of consumers using gastronomy during the epidemic, fifteen variables describing consumer behavior and five variables describing consumers were used. As a result of the agglomeration of variables, strongly related variables were removed, leaving one representative for each group of related variables. The variables Q9.1, Q.10.1, Q.25.4 and Q.25.5 and the variables describing the respondents remained in the analysis. Based on the cases agglomeration diagram, the optimal number of clusters was determined to be eight. The physical division of the sample into clusters 
was performed using the k-means method. The values of medians calculated for each of the variables in the cluster were used to describe the cluster.

On the basis of the median values (Figure 2), it can be concluded that the group consisting of clusters from 1 to 4 are people who do not have any anxiety using gastronomy during an epidemic (Table 6). These are people who were not afraid of using catering services, felt safe while using them both inside and outside the premises, did not limit the activities during which you can use catering services, and were not afraid of infection by COVID-19. Cluster 5 consisted of people who do not have concerns about the use of gastronomy, but had to limit the use of food services due to the introduced restrictions. Clusters 6-8 grouped people who were afraid of using food services during the pandemic and were restricting use of services due to concerns about getting sick. It was their intentional and conscious action.

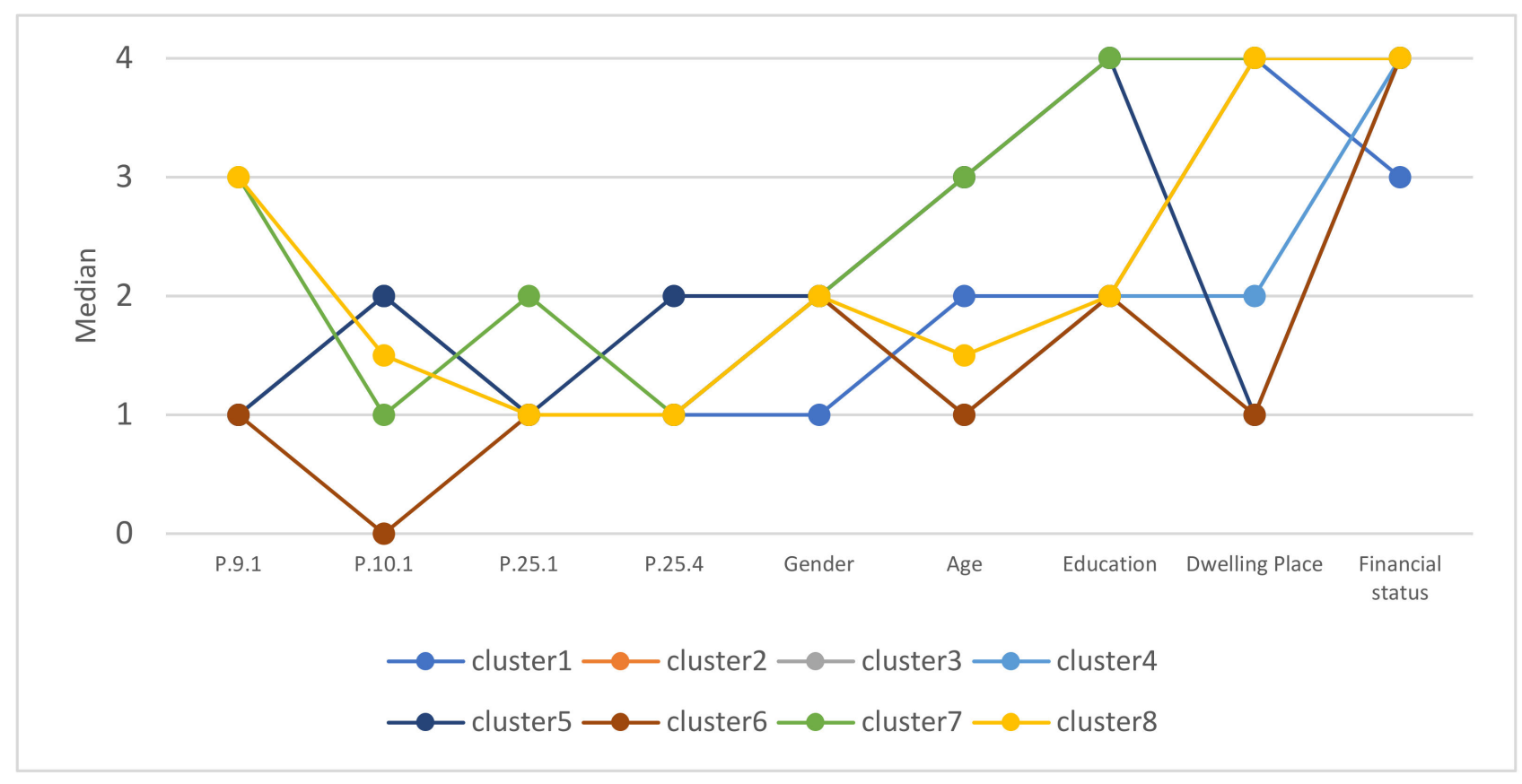

Figure 2. Medians of selected characteristics for observations in different clusters due to both related to the epidemic.

Based on segmentation, it can be concluded that the majority of respondents do not see any threats to the use of catering services, do not care about potential problems, and do not intend to change their approach to this type of service due to concerns about the possibility of getting sick with COVID-19.

\subsection{The Use of Food Delivery from Gastronomy to Home by the Respondents}

A significant percentage of respondents used home delivery food services (87.5\%). The respondents most often used direct food delivery from catering establishments (58.1\%), which they used rarely more than once every two or three months. The other internet portals or applications respondents used them sporadically during the year. Respondents reported that they used apps such as Uber Eats (34.4\%), Glovo (19.1\%), and Polish equivalent of apps Just Eat Takeaway.com (49.9\%), Bolt Food (9.4\%), Wolt (7.1\%), and local on-line delivery food platforms $(11.7 \%)$. Using food delivery to home was dependent on gender, age, education, dwelling place, and financial status $(p<0.005)$. Using local on-line delivery food platforms depended only on gender $(p=0.029)$. This delivery form was usually used by young people up to 25 years old. Payments were usually made online $(43.9 \%)$ or by credit card $(35.8 \%)$. However, $11.7 \%$ of people paid for the delivery in cash. 
Table 6. Cluster analysis results for consumer anxiety about the use of food services during a pandemic.

\begin{tabular}{|c|c|c|c|}
\hline Cluster & $\begin{array}{l}\text { Number of } \\
\text { Respondents } \\
(\%)\end{array}$ & $\begin{array}{c}\text { Characteristic of an Average } \\
\text { Representative }\end{array}$ & Anxiety \\
\hline Cluster 1 & $220(21.5 \%)$ & $\begin{array}{c}\text { young men ( } 26-40 \text { years old), with secondary } \\
\text { school education, living in large cities } \\
(>250,000 \text { inhabitants), with a good financial } \\
\text { situation }\end{array}$ & They haven't \\
\hline Cluster 2 & $167(16.4 \%)$ & $\begin{array}{c}\text { young women }(18-25 \text { years old), with } \\
\text { secondary school education, living in large } \\
\text { cities ( }>250,000 \text { inhabitants), with a good } \\
\text { financial situation }\end{array}$ & They haven't \\
\hline Cluster 3 & $110(10.8 \%)$ & $\begin{array}{l}\text { women } 41-55 \text { years old, with higher } \\
\text { education, living in large cities (>250,000 } \\
\text { inhabitants), with a good financial situation }\end{array}$ & They haven't \\
\hline Cluster 4 & $187(18.3 \%)$ & $\begin{array}{l}\text { young women ( } 18-25 \text { years old), with } \\
\text { secondary school education, living in village } \\
\text { and city below } 10,000 \text { inhabitants, with a } \\
\text { good financial situation }\end{array}$ & They haven't \\
\hline Cluster 5 & $85(8.3 \%)$ & $\begin{array}{c}\text { women } 41-55 \text { years old, with higher } \\
\text { education, living in village and city below } \\
10,000 \text { inhabitants }\end{array}$ & $\begin{array}{l}\text { They haven't, and they did not change the } \\
\text { behavior in gastronomy, except for those } \\
\text { related to the participation in sports, cultural } \\
\text { and other events (administrative } \\
\text { restrictions). }\end{array}$ \\
\hline Cluster 6 & $87(8.5 \%)$ & $\begin{array}{l}\text { young women (18-25 years old), with } \\
\text { secondary school education, living in village } \\
\text { and city below } 10,000 \text { inhabitants }\end{array}$ & $\begin{array}{l}\text { No opinion about the safety risks when } \\
\text { using the food services. They did not change } \\
\text { their behavior because they didn't orientate } \\
\text { in pandemic topic. }\end{array}$ \\
\hline Cluster 7 & $83(8.1 \%)$ & $\begin{array}{c}\text { women } 41-55 \text { years old, with higher } \\
\text { education, living in big cities }(>250,000 \\
\text { inhabitants and city between 50,000-250,000 } \\
\text { inhabitants) }\end{array}$ & $\begin{array}{l}\text { They are concerned about the safety of food } \\
\text { services (aware of the dangers) }\end{array}$ \\
\hline Cluster 8 & $82(8.0 \%)$ & $\begin{array}{l}\text { young women (18-25 and } 26-40 \text { years old) } \\
\text { with secondary school education, living in } \\
\text { large cities (>250,000 inhabitants) }\end{array}$ & $\begin{array}{l}\text { They are concerned about the safety of food } \\
\text { services and do not use them in an epidemic, } \\
\text { but also rarely used them before a pandemic }\end{array}$ \\
\hline
\end{tabular}

During delivery, the supplier handed over the order from a distance while maintaining the sanitary regime (59.2\% of indications), or delivered and left it at the door $(22.3 \%)$. A small percentage $(5.9 \%)$ of the study participants reported hygiene non compliances during food delivery.

\section{Discussion}

The obtained results indicate a change in eating habits and consumer behavior related to the use of catering services by Poles. This is interesting because, despite the prevailing pandemic, there is no evidence that COVID-19 is transmitted through food consumption [88-92]. However, infection can occur by inhaling the virus within $1 \mathrm{~m}$ of a COVID-19 infected person, or by touching a contaminated surface and then touching the eyes, nose, or mouth before washing hands [91]. For this reason, eating in restaurants during an outbreak can be viewed as high risk due to the possibility of infection in a closed dining room and contact with service providers and other customers.

According to this research, respondents limited the use of on-premises catering services and preferred the option of ordering take-away food, food delivery for home and work, or a drive-thru (after the opening of catering establishments during pandemic). Yang et al. [53] found that a $1 \%$ increase in daily new COVID-19 cases led to a $0.0556 \%$ decrease 
in restaurant demand while stay-at-home orders were associated with a $3.25 \%$ demand decline.

In March and April 2020, restaurants in the U.S. recorded a significant increase in orders for food delivery on the Uber Eats platform [93], and these consumers (who were highly afraid of the COVID-19) chose a private dining restaurant and a private dining table [51]. Mobility restrictions, the lockdown, and the closure of catering establishments have led to a sharp decline in consumer demand for lunch restaurants. The number of consumers eating lunches in gastronomy fell in March 2020 to the lowest level in history in many countries due to strict sanitary rules [37]. Another reason could be that consumers are more likely to limit their spending on meals outside the home, because cooking at home, especially for larger households, is cheaper [53,94]. Moreover, studies have shown that consumers had more time to prepare meals during the pandemic $[60,62]$.

As shown, among the 8 clusters selected in the analyses in terms of respondents' concerns about the pandemic, only a small group of people $(8.1 \%)$ feared for their health while using food services during the pandemic. Nevertheless, they limited use of food services due to work or online learning and limited some activities, including tourism and entertainment.

The respondents mentioned the quality of the dishes, the price, the possibility of delivery, and delivery time as the most important factors in choosing catering services during the pandemic. The quality of services provided during the COVID-19 epidemic may result in increased loyalty to catering establishments after its end [22]. It is interesting that maintaining the sanitary and hygienic regime were mentioned subsequently. This may be due to the fact that the pandemic has forced people to eat their food off-site from establishments and caused many critical changes to food services. In response to the COVID-19 crisis, gastronomy has adapted various operating strategies, including changes in service delivery methods [95,96], adoption of new technology [97], and strict compliance with hygiene and safety standards [98].

Catering establishments have implemented alternative models of providing services outside the premises, such as drive-thru and direct food delivery or ordering using an application and delivery through external companies such as Uber Eats, Bolt, and others. Non-cash payment and sanitary procedures have been implemented to make consumers feel safe, so that they did not have to give up their eating habits. However, these service models often provide an advantage to fast food restaurants that already had digital infrastructure and drive-thrue. Not all full-service restaurants were able to quickly adapt to change [99]. The COVID-19 pandemic differs from other food organization crises because of its severity, devastating effects, evolving nature, and the very limited way organizations were able to control the situation. The catering sector faced new challenges, starting with disruptions in the supply chain, changing market demand, maintaining a high level of food safety, and maintaining consumer confidence [92,100-105].

Respondents were good observers of maintaining hygiene and ensuring consumer safety during a pandemic, both while staying at the premises and ordering food for home or work. Consumers' sense of security when using catering services is associated with the perception of the risk of contracting the COVID-19 virus. It should be remembered that the lack of safeguards may deter consumers from eating during a pandemic where there is a high risk of infection [52]. The respondents considered the following the most important forms of protection during the pandemic: hand disinfection $(70.3 \%)$, table disinfection $(70.4 \%)$, wearing of masks and visors by staff $(68.2 \%)$, the possibility of making cashless payments (64.6\%), and maintaining social distance (59.2\%). According to studies [7,89,91,106,107], washing and disinfection of hands by staff and customers, wearing disposable gloves by staff, as well disinfection of all contact surfaces (dishes, trays, tables, handles, doors, chairs, dispensers) are the most important and critical activities undertaken in order to limit the spread of the virus and avoid disease [7,89,91,106,107]. Catering establishments should also install plexiglass partitions in order to increase the distance and separate employees 
from guests or between consumers [108]. It should be emphasized that, unfortunately, in many places these rules were not applied, which was pointed out by the respondents.

During the pandemic, respondents most often used pizzerias, fast food establishments, restaurants and cafes, followed by establishments offering Asian food and kebab bars. These are the establishments that Polish consumers also used most often before the pandemic. Fast-food restaurants offer more options for take-away service that enable consumers to take advantage of the service without staying on the premises. Yang et al. [36] found a lower negative impact of COVID-19 when using nutrition in fast food restaurants compared to full-service establishments. A full cycle of waiter service in restaurants can increase consumers' perception of contagion risk. Consumers may therefore have a different perception of the contagion risk related to eating meals in fast-food restaurants compared to full-service restaurants [36]. COVID-19 disease can be spread through physical contact, which is limited in fast food restaurants, which may contribute to the perception of lower risk in these establishments. The ongoing COVID-19 pandemic and related global restrictions have caused an economic crisis, and consumer spending has largely decreased accordingly [109]. Hence, consumers are more likely to avoid gourmet meals and look for cheaper options of meals, such as fast food. People with low incomes, and with low education, mainly use fast-food establishments. The restaurants are chosen mainly by people with average and high income which is usually connected with high education $[72,110,111]$.

Only half of the respondents reported changes in their diet due to the pandemic. They included greater attention to their diet, limited consumption of sweets, meat, and fats, and reduced caloric value of meals. However, $20 \%$ of respondents reported drinking more alcohol, eating more sweets, not paying attention to the energy value of meals, and consuming more fats and carbs. The nutritional changes, both positive and negative, also indicated by other authors [66,112]. Similar results were stated in Italy. There was an improvement in the consumption of components of the nutritional pattern in the Mediterranean population. Natural products such as garlic, sage, and olive oil have been proposed that are inherent in this diet as additional measures to prevent and treat COVID-19 [61,66].

Similar relationships are also indicated by other authors, including an increase in consumption of animal products and snacks [53,113], increasing salty snacks [32], increasing fat consumption [31], increasing 'junk food' consumption [61], snacking between meals [59], increased use of alcohol [65], and increasing sweets [34,65], especially during the lockdown. Authors $[35,69,114]$ indicated that the stress associated with pandemic influenced on increases in emotional food of consumption, tasty but with high energy value. It should be emphasized that poor food choices in the long term could result in increased risk factors for cardiovascular diseases, diabetes, and cancer [115]. Many authors also noted positive changes, such as an increase in the consumption of vegetables and fruits, legumes, and fish [32,33,63,67]. At the beginning of the COVID-19 pandemic, some authors $[31,68,116-119]$ have found an increase in the consumption of long-life foods, and a decrease in the consumption of fresh-from-food. Authors $[68,119]$ explained that the limitation of vegetable and fruits consumption was connected with its low quality, poor availability, high price, and decrease frequency of shopping by consumers.

Among the positive effects of the pandemic in Polish gastronomy, there was an increase in interest in catering for all-day meals for private individuals (the so-called box diets). These types of meals are often of a dietary nature or are profiled for specific recipients (physically active people, athletes, vegans, etc.) [18].

\section{Limitations}

This study has some limitations in terms of both its methodology and its applica-bility. The sample selected for the study consisted mainly of people between 18 and 55 years old; therefore, caution should be exercised in attempting to extrapolate the results to an entire population. In addition, the study was conducted mainly in large Polish cities. Consumers' 
behavior may be different in other places. Another limitation is that the respondents were from only one country. Despite the limitations, the results obtained are of practical importance, and demonstrate the nutritional behavior of consumers during a pandemic, especially in catering establishments.

\section{Conclusions}

Almost half of the respondent group did not change their diet during the pandemic. About $20 \%$ of people began to pay attention to their diet, especially to the energy value of meals, and limited the consumption of sweets, meat, and fats. About $20 \%$ of respondents drank more alcohol, ate more sweets, consumed more fats and carbs, and didn't pay attention to the energy value of their diet. They also did not change their habits of preparing home meals and prepared them several times a week. It was found that COVID-19 had an impact on consumers' use of food services, both on-site and take-away. Due to the online mode of work and teaching, as well as the limitations on tourist and entertainment activities, the use of restaurants was limited in favor of home and work deliveries. The type of dishes ordered by respondents did not change and was similar to before the pandemic. Five consumer clusters were identified, differing in terms of the frequency of using various forms of catering services, including specialist portals and food ordering applications.

A majority of respondents (about 70\%) considered the following as the most important forms of protection during the pandemic when using food services, hand disinfection, table disinfection, wearing of masks and visors by staff, and the possibility of cashless payments. However, respondents indicated that their use of gastronomic services sometimes raised concerns due to non-compliance with hygiene rules in establishments. Due to concerns about using catering services, eight consumer clusters were identified. Only two clusters of respondents who were concerned about the safety of food service and consciously limited use of these services were selected. The pandemic has affected eating behavior of respondents in catering establishments but have not changed the consumers' habits. It is worth paying attention to further research on the subject. Researchers conducting their studies in different countries will be able to better understand the consequences are of the pandemic in gastronomic sector but their inhabitants will have different food preferences and thus their behavioral changes may differ from herein.

Author Contributions: Conceptualization, E.C.-S. and M.P.; methodology, E.C.-S. and M.P.; investigation, E.C.-S., M.P., P.S., A.G. and J.K.-C.; data curation, E.C.-S. and T.O.; writing-original draft preparation, E.C.-S., M.P., P.S., A.G.; writing—review and editing, E.C.-S., M.P., P.S.; visualizationM.P. and P.S. supervision, E.C.-S. All authors have read and agreed to the published version of the manuscript.

Funding: This research was financed by the Polish Ministry of Science and Higher Education within funds of Institute of Human Nutrition Sciences, Warsaw University of Life Sciences (WULS) for scientific research.

Institutional Review Board Statement: The study protocol was approved by the Ethics Committee of the Institute of Human Nutrition Sciences of the Warsaw University of Life Sciences (no. 12/2021).

Informed Consent Statement: Informed consent was obtained from all subjects involved in the study.

Data Availability Statement: The data presented in this article is available on reasonable request, from the corresponding author.

Conflicts of Interest: The authors declare no conflict of interest. 


\section{Appendix A}

Table A1. Questionnaire structure.

\begin{tabular}{|c|c|}
\hline Question & Variants of Answers \\
\hline Q1. Did you use catering services before the pandemic? & Choose the right answer: (1): yes, (2): no \\
\hline $\begin{array}{l}\text { Q2. How often (before the pandemic) did you use a particular } \\
\text { category of catering services? Q2.1. on-site/dine in, Q2.2. } \\
\text { Take-out/drive-thru, Q2.3. Home/work delivery }\end{array}$ & $\begin{array}{l}\text { (8): every day, (7): three or four times a week, (6): once a week, (5): } \\
\text { two-three times a month, (4): once a month, (4): once a } \\
2-3 \text { months, (2): rarely than once a } 2 \text { a } 2-3 \text { month, (1): I did not use }\end{array}$ \\
\hline $\begin{array}{l}\text { Q3. Which catering establishments did you use (before the } \\
\text { pandemic) and how often? Q3.1. canteens, buffets, Q3.2. } \\
\text { fast-food, Q.3.3. full-service restaurants, Q3.4. pizzerias, Q3.5. } \\
\text { kebab house, Q3.6. Asian restaurants, Q3.7. cafes and bars, } \\
\text { Q.3.8. motorway service station, Q3.9. street-food vendors }\end{array}$ & $\begin{array}{l}\text { (8): every day, (7): three or four times a week, (6): once a week, (5): } \\
\text { two-three times a month, (4): once a month, ( } 3 \text { ): once a } 2-3 \\
\text { months, (2) rarely than once a } 2-3 \text { month, } \\
\text { (1) I did not use }\end{array}$ \\
\hline Q4. Do you prepare meals at home? & Choose the right answer: yes (1), no (0) \\
\hline $\begin{array}{l}\text { Q5. How often do you cook at home? } \\
\text { Q5.1. before pandemic, Q5.2 during a pandemic }\end{array}$ & $\begin{array}{l}\text { (8): every day, (7) three or four times a week, (6) once a week, (5) } \\
\text { two-three times a month, (4) once a month, (3) once a } 2-3 \text { months, } \\
\text { (2) rarely, (1) I did not use }\end{array}$ \\
\hline $\begin{array}{l}\text { Q6. Do you refrain from leaving home to a minimum during } \\
\text { the pandemic? }\end{array}$ & Choose the right answer: (1): yes, (2): no \\
\hline Q7. Do you use catering services during a pandemic? & Choose the right answer: (1): yes, (2): no \\
\hline $\begin{array}{l}\text { Q8. If yes, please specify which category and how often do } \\
\text { you use them? 8.1. home/work delivery, 8.2. Take } \\
\text { away/drive thru, } \\
\text { 8.3. on-site (after opening the premises)/dine in }\end{array}$ & $\begin{array}{l}\text { (8): every day, (7) three or four times a week, (6) once a week, (5) } \\
\text { two-three times a month, (4) once a month, (3) once a } 2-3 \text { months, } \\
\text { (2) rarely, (1) I did not use }\end{array}$ \\
\hline
\end{tabular}

Q9. Were you afraid to use catering services?

Q9.1. period when consumption on-premises was not possible,

Q9.2. period after the opening of the dining area on-premise.

Q10. Did you feel safe using various catering services?

Q10.1. Home/work delivery, Q10.2. take away/drive thru, Q10.3. On-site (after opening the premises)/dine in

(4): always, (3): often, (2): sometimes, (1): never

Q11. What type of safety practices have been used in catering services? Q11.1 Distance of two meters from other people, Q11.2. Plexiglass partitions, Q11.3. hand disinfection, Q11.4. staff wearing disposable gloves, Q11.5. staff wearing protective masks or visors, Q11.6. disinfection of tables, Q11.7. cashless payment availability, Q11.8. disinfection of payment terminals, Q11.9. other non-compliances

Q12. What other safety non compliances were found while using catering services?

Choose the right answer: (1): yes, (2): no, (0): I have no opinion

Q13. Did you pick up the order from the restaurant by yourself?

Choose the right answer:

(1) Home/work delivery,

(2) take out/drive-thru,

(3) on-site (after opening the premises)/dine in

Please specify

Q14. What protective practices were important for you when preparing/serving/consuming a meal on-site in a catering establishment? Q14.1. Distance of $2 \mathrm{~m}$ from other people, Q14.2. Plexiglass partitions, Q14.3. hand disinfection, Q14.4. staff wearing disposable gloves, Q14.5. staff wearing protective masks or visors, Q14.6. disinfection of tables, Q14.7. cashless payment availability, Q14.8 disinfection of payment terminals, Q14.9. Other (Please specify).

Q15. What online food delivery platforms/mobile apps did you use the during the pandemic?: 15.1: Uber Eats, 15.2: Glovo, 15.3: Just Eat Takeaway.com (in Poland Pyszne.pl), 15.4: Smacznie i szybko.pl, 15.5: Głodny.pl, 15.6: Pizza.pl, 15.7: (6) every day, (5) three or four times a week, (4) once a week, (3) Bolt Food, 15.8: Wolt, 15.9: Delivery from establishments, 15.10: Other (Please specify)

Choose the right answer: (5): very important, (4): important, (3): neutral, (2): low importance, (1): not at all important 
Table A1. Cont.

\begin{tabular}{|c|c|}
\hline Question & Variants of Answers \\
\hline Q16. What delivery methods did you usually use? & $\begin{array}{l}\text { (1): delivery and leave food at the door, (2): delivery food with } \\
\text { hygienic rules, (3): other non compliances }\end{array}$ \\
\hline Q17. How did you usually make the payment? & Using: (1) a payment card, (2) cash, (3) pre-paid \\
\hline $\begin{array}{l}\text { Q18. What did you pay attention to when ordering during the } \\
\text { pandemic? Q18.1. quality of dishes, Q18.2. price, Q18.3. brand, } \\
\text { Q18.4. opinion and popularity of the establishment, Q18.5. } \\
\text { sense of security, Q18.6. nutritional value, Q18.7. possibility to } \\
\text { order meals: vegan, low fat, gluten free, Q18.8. assurance } \\
\text { hygienic practices, Q18.9. order fulfillment time, Q18.10. } \\
\text { delivery availability }\end{array}$ & $\begin{array}{l}\text { (1): strongly disagree, } \\
\text { (2): disagree, } \\
\text { (3): somewhat disagree, } \\
\text { (4): neither agree nor disagree, } \\
\text { (5) somewhat agree, (6) agree, } \\
\text { (7) strongly agree }\end{array}$ \\
\hline
\end{tabular}

Q19. What dishes and how often did you usually order during the pandemic? Q19.1. Special offer menu items, Q19.2. Traditional lunch meals, Q19.3. American Cuisine, Q19.4. Pizza, Q19.5. Salads and fit meals, Q19.6. Pastas, Q19.7. Sushi, Q19.8. Asian cuisine, Q19.9. Street food, Q19.10. Special Diet Meals (e.g., gluten free), Q19.11. Indian cuisine, Q19.12. Desserts, Q19.13. Fast-food, Q19.14. Other (Please specify)

(1): never,

(2): once or two a month,

(3): three-four times a month,

(4): once a week,

(5): two or three times a week,

(6): every day

Q20. Have you noticed any special offers when ordering meals during the pandemic? Multiple choice answers

(1): special discount coupons, (2): discounts (e.g., $-50 \%$ ), (3): freebies, bonuses (e.g., beverage for free, buy one, get one free), (4): I have not noticed, (5): other (please specify)

(1): It did not change, (2): I started to take care of my diet, (3): I have eaten more vegetarian dishes, (4): I have limited sweets consumption, (5): I have limited meat consumption, (6): I have

Q21. Have your diet changed during the pandemic? Multiple choice answers limited fat consumption, (7): I have paid attention to the caloric value of the meals, (8): I have not paid attention to the caloric value of the meals, (9): I have eaten more sweets, (10): I have drunk more alcohol, (11): I have consumed more fat/carbs

Q.22. Do you agree with the statement: 'The quality of catering services during the pandemic was provided at the highest level'

Q23. When do you intend to use the catering services on the restaurant premise?

(1): strongly disagree, (2): disagree, (3): somewhat disagree, (4): neither agree or disagree, (5) somewhat agree, (6) agree, (7) strongly agree

(1): When the pandemic will end, (2): When the daily number of new COVID-19 cases in my region/city will be close to zero, (3): I do not know, (4): I did it as soon as it was possible, (5): I use it respecting the principle of hygiene and social distancing

(1): Fear of COVID-19 infection, (2): Financial reasons (reduction of income, savings), (3): Work or remote learning (less frequency of business meetings, online classes), (4): Limited tourist activity (traveling, sightseeing, using hotels), (5): Limited activity in cultural events (cinema, theater, concerts),

Q24. If you have limited the frequency of using catering services, please indicate the reasons for your decision.

(6): Limited activity in shopping centers, (7): Restriction of movement (petrol stations, airports, railway stations), (8): Discomfort related to the restrictions in catering industry, (9): Limitation in the organization of social event catering (e.g., wedding), (10): Other (Please specify).

\section{References}

1. Bienkov, A. Coronavirus: Loss of smell and taste may be hidden symptom of COVID-19. Business Insider, 28 March 2020. Available online: https:/ / www.businessinsider.com/coronavirussymptoms-loss-of-smell-taste-covid-19-anosmia-hyposmia2020-3 (accessed on 6 May 2021).

2. Centers for Disease Control and Prevention (CDC). Symptoms of Coronavirus. 2020. Available online: https://www.cdc.gov / coronavirus/2019-ncov/symptomstesting/symptoms.html (accessed on 10 May 2021).

3. Fernández-Quintela, A.; Milton-Laskibar, I.; Trepiana, J.; Gómez-Zorita, S.; Kajarabille, N.; Léniz, A.; González, M.; Portillo, M.P. Key Aspects in Nutritional Management of COVID-19 Patients. J. Clin. Med. 2020, 9, 2589. [CrossRef] [PubMed] 
4. Pomara, C.; Li Volti, G.; Cappello, F. COVID-19 Deaths: Are We Sure It Is Pneumonia? Please, Autopsy, Autopsy, Autopsy! J. Clin. Med. 2020, 9, 1259. [CrossRef]

5. Salerno, M.; Sessa, F.; Piscopo, A.; Montana, A.; Torrisi, M.; Patanè, F.; Murabito, P.; Li Volti, G.; Pomara, C. No Autopsies on COVID-19 Deaths: A Missed Opportunity and the Lockdown of Science. J. Clin. Med. 2020, 9, 1472. [CrossRef] [PubMed]

6. Zhou, F.; Yu, T.; Du, R.; Fan, G.; Liu, Y.; Liu, Z.; Xiang, J.; Wang, Y.; Song, B.; Gu, X.; et al. Clinical course and risk factors for mortality of adult inpatients with COVID-19 in Wuhan, China: A retrospective cohort study. Lancet 2020, 395, 1054-1062. [CrossRef]

7. Shahbaz, M.; Bilal, M.; Moiz, A.; Zubair, S.; Iqbal, H.M. Food safety and COVID-19: Precautionary measures to limit the spread of coronavirus at food service and retail sector. J. Pure Appl. Microbiol. 2020, 14 (Suppl. 1), 749-756. [CrossRef]

8. Gupta, S.; Nguyen, T.D.; Rojas, F.L.; Raman, S.; Lee, B.; Bento, A.; Simon, K.I.; Wing, C. Tracking Public and Private Responses to the COVID-19 Epidemic: Evidence from State and Local Government Actions; NBER Working Papers, Series 27027; National Bureau of Economic Research Inc.: Cambridge, MA, USA, 2020. Available online: http:/ /www.nber.org/papers/w27027.pdf (accessed on 6 May 2021).

9. Killeen, B.D.; Wu, J.Y.; Shah, K.; Zapaishchykova, A.; Nikutta, P.; Tamhane, A.; Chakraborty, S.; Wei, J.; Gao, T.; Thies, M.; et al. A County-Level Dataset for Informing the United States' Response to COVID-19. arXiv 2020, arXiv:2004.00756. Available online: https: / / arxiv.org/abs/2004.00756 (accessed on 6 May 2021).

10. Burki, T. Outbreak of coronavirus disease. Lancet Infect. Dis. 2020, 20, 292-293. [CrossRef]

11. Jiang, S.; Xia, S.; Ying, T.; Lu, L. A novel coronavirus (2019-nCoV) causing pneumonia-associated respiratory syndrome. Cell. Mol. Immunol. 2020, 17, 554. [CrossRef] [PubMed]

12. Cucinotta, D.; Vanelli, M. WHO Declares COVID-19 a Pandemic. Acta Bio Med. 2020, 91, 57-160. [CrossRef]

13. Uğur, N.G.; Akbıyık, A. Impacts of COVID-19 on global tourism industry: A cross-regional comparison. Tour. Manag. Perspect. 2020, 36, 100744. [CrossRef] [PubMed]

14. Sidor, A.; Rzymski, P. Dietary choices and habits during COVID-19 lockdown: Experience from Poland. Nutrients 2020, $12,1657$. [CrossRef]

15. Błaszczyk-Bębenek, E.; Jagielski, P.; Bolesławska, I.; Jagielska, A.; Nitsch-Osuch, A.; Kawalec, P. Nutrition Behaviors in Polish Adults before and during COVID-19 Lockdown. Nutrients 2020, 12, 3084. [CrossRef] [PubMed]

16. Statistics Poland. Business Tendency in Manufacturing, Construction, Trade and Services 2000-2021 (February 2021) with Annexes. Available online: https://stat.gov.pl/download/gfx/portalinformacyjny/en/defaultaktualnosci/3327/1/47/1/btsfebruary-2021.pdf (accessed on 15 April 2021).

17. Statistics Poland. Business Tendency in Manufacturing, Construction, Trade and Services 2000-2021 (March 2021) with Annexes. Available online: https:/ / stat.gov.pl/download/gfx/portalinformacyjny/en/defaultaktualnosci/3327/1/48/1/bts-march-20 21.pdf (accessed on 15 April 2021).

18. Tarnawa, Ł.; Peterlik, M. Raport branżowy. Analizy Sektorowe. 12 Kwietnia 2021. Działalność Usługowa Związana z Wyżywieniem (PKD 56). Available online: https://www.bosbank.pl/_data/assets/pdf_file/0028/34957/BOSBank_Restauracje_2021.04. pdf (accessed on 15 May 2021).

19. Kaushal, V.; Srivastava, S. Hospitality and tourism industry amid COVID-19 pandemic: Perspectives on challenges and learnings from India. Int. J. Hosp. Manag. 2021, 92, 102707. [CrossRef]

20. Baker, S.R.; Farrokhnia, R.A.; Meyer, S.; Pagel, M.; Yannelis, C. How Does Household Spending Respond to an Epidemic? Consumption during the COVID-19 Pandemic. Working Paper. 2020. Available online: https://www.nber.org/papers/w26949 .pdf (accessed on 14 May 2021).

21. U.S. Travel Association. The Great Travel Depression. 2020. Available online: https://www.ustravel.org/sites/default/files/ media_root/document/TravelDepression_FactSheet.pdf (accessed on 7 May 2021).

22. Chen, W.-K.; Riantama, D.; Chen, L.-S. Using a Text Mining Approach to Hear Voices of Customers from Social Media toward the Fast-Food Restaurant Industry. Sustainability 2021, 13, 268. [CrossRef]

23. Chang, C.-P.; Feng, G.-F.; Zheng, M. Government Fighting Pandemic, Stock Market Return, and COVID-19 Virus Outbreak Emerg. Mark. Financ. Trade 2021, 57, 2389-2406. [CrossRef]

24. European Parliament. Covid-19 and the Tourism Sector. 2020. Available online: https:/ /www.europarl.europa.eu/RegData/ etudes/ATAG/2020/649368/EPRS_ATA(2020)649368_EN.pdf (accessed on 14 April 2021).

25. Lasek, A.; Cercone, N.; Saunderrs, J. Smart Restaurants: Survey on Customer Demand and Sales Forecasting. In Smart Cities and Homes. KeyEnabling Technologies; Obaidat, M.S., Nicopolitidis, P., Eds.; Morgan Kaufmann Publisher Inc.: Burlington, MA, USA, 2016; Chapter 17; pp. 361-386. [CrossRef]

26. Ferrer, R.A.; Klein, W.M. Risk perceptions and health behavior. Curr. Opin. Psychol. 2015, 5, 85-89. [CrossRef]

27. Garbe, L.; Rau, R.; Toppe, T. Influence of Perceived Threat of Covid-19 and HEXACO Personality Traits on Toilet Paper Stock piling. PLoS ONE 2020, 15, e0234232. [CrossRef] [PubMed]

28. Pérez-Rodrigo, C.; Gianzo Citores, M.; Hervás Bárbara, G.; Ruiz-Litago, F.; Casis Sáenz, L.; Arija, V.; López-Sobaler, A.M.; Martínez de Victoria, E.; Ortega, R.M.; Partearroyo, T.; et al. Patterns of Change in Dietary Habits and Physical Activity during Lockdown in Spain Due to the COVID-19 Pandemic. Nutrients 2021, 13, 300. [CrossRef]

29. Wu, P.; Liu, X.; Fang, Y.; Fan, B.; Fuller, C.J.; Guan, Z.; Yao, Z.; Kong, J.; Lu, J.; Litvak, I.J. Alcohol abuse/dependence symptoms among hospital employees exposed to a SARS outbreak. Alcohol 2008, 43, 706-712. [CrossRef] 
30. Razzoli, M.; Bartolomucci, A. The Dichotomous Effect of Chronic Stress on Obesity. Trends Endocrinol. Metab. 2016, $27,504-515$. [CrossRef] [PubMed]

31. Murphy, B.; Benson, T.; McCloat, A.; Mooney, E.; Elliott, C.; Dean, M.; Lavelle, F. Changes in Consumers' Food Practices during the COVID-19 Lockdown, Implications for Diet Quality and the Food System: A Cross-Continental Comparison. Nutrients 2021, 13, 20. [CrossRef]

32. Androutsos, O.; Perperidi, M.; Georgiou, C.; Chouliaras, G. Lifestyle Changes and Determinants of Children's and Adolescents' Body Weight Increase during the First COVID-19 Lockdown in Greece: The COV-EAT Study. Nutrients 2021, 13, 930. [CrossRef] [PubMed]

33. Dragun, R.; Veček, N.N.; Marendić, M.; Pribisalić, A.; Đivić, G.; Cena, H.; Polašek, O.; Kolčić, I. Have Lifestyle Habits and Psychological Well-Being Changed among Adolescents and Medical Students Due to COVID-19 Lockdown in Croatia? Nutrients 2021, 13, 97. [CrossRef]

34. Maffoni, S.; Brazzo, S.; De Giuseppe, R.; Biino, G.; Vietti, I.; Pallavicini, C.; Cena, H. Lifestyle Changes and Body Mass Index during COVID-19 Pandemic Lockdown: An Italian Online-Survey. Nutrients 2021, 13, 1117. [CrossRef]

35. Sadler, J.R.; Thapaliya, G.; Jansen, E.; Aghababian, A.H.; Smith, K.R.; Carnell, S. COVID-19 Stress and Food Intake: Protective and Risk Factors for Stress-Related Palatable Food Intake in U.S. Adults. Nutrients 2021, 13, 901. [CrossRef]

36. Yang, Y.; Liu, H.; Chen, X. COVID-19 and restaurant demand: Early effects of the pandemic and stay-at-home orders. Int. J. Contemp. Hosp. Manag. 2020, 32, 3809-3834. [CrossRef]

37. Dube, K.; Nhamo, G.; Chikodzi, D. COVID-19 cripples global restaurant and hospitality industry. Curr. Issues Tour. 2020, 24, 1487-1490. [CrossRef]

38. Rizou, M.; Galanakis, I.M.; Aldawoud Turki, M.S.; Galanakis, C.M. Safety of foods, food supply chain and environment within the COVID-19 pandemic. Trends Food Sci. Technol. 2020, 102, 293-299. [CrossRef]

39. Namkung, Y.; Jang, S. Does food quality really matter in restaurants? Its impact on customer satisfaction and behavioral intentions. J. Hosp. Tour. Res. 2007, 31, 387-409. [CrossRef]

40. Fatimah, U.Z.A.U.; Boo, H.C.; Sambasivan, M.; Salleh, R. Foodservice hygiene factors-the consumer perspective. Int. J. Hosp . Manag. 2011, 30, 38-45. [CrossRef]

41. Kwun, J.-W.; Oh, H. Effects of Brand, price, and risk on customers' value perceptions and behavioral intentions in the restaurant industry. J. Hosp. Mark. Manag. 2004, 1, 31-49. [CrossRef]

42. Duarte Alonso, A.; O'neill, M.; Liu, Y.; O'shea, M. Factors driving consumer restaurant choice: An exploratory study from the Southeastern United States. J. Hosp. Mark. Manag. 2013, 22, 547-567. [CrossRef]

43. Yang, Y.; Roehl, W.S.; Huang, J.-H. Understanding and projecting the restaurant scape: The influence of neighborhood sociodemographic characteristics on restaurant location. Int. J. Hosp. Manag. 2017, 67, 33-45. [CrossRef]

44. Kim, W.G.; Li, J.J.; Brymer, R.A. The impact of social media reviews on restaurant performance: The moderating role of excellence certificate. Int. J. Hosp. Manag. 2016, 55, 41-51. [CrossRef]

45. Becker, C. How a natural disaster changed the face of the restaurant industry in Southern Mississippi: A Katrina story. J. Foodserv. Bus. Res. 2009, 12, 266-274. [CrossRef]

46. Lee, K.; Ha, I. Exploring the impacts of key economic indicators and economic recessions in the restaurant industry. J. Hosp. Mark. Manag. 2012, 21, 330-343. [CrossRef]

47. Koh, Y.; Lee, S.; Choi, C. The income elasticity of demand and firm performance of US restaurant companies by restaurant type during recessions. Tour. Econ. 2013, 19, 855-881. [CrossRef]

48. Reynolds, D.; Rahman, I.; Balinbin, W. Econometric modeling of the US restaurant industry. Int. J. Hosp. Manag. 2013, 34, 317-323. [CrossRef]

49. Lee, K.; Ha, I. How do economic recessions affect the US restaurant industry? J. Foodserv. Bus. Res. 2014, 17, 353-362. [CrossRef]

50. Tse, A.C.B.; So, S.; Sin, L. Crisis management and recovery: How restaurants in Hong Kong responded to SARS. Int. J. Hosp. Manag. 2006, 25, 3-11. [CrossRef]

51. Kim, J.; Kim, J.; Lee, S.K.; Tang, L.R. Effects of epidemic disease outbreaks on financial performance of restaurants: Event study method approach. J. Hosp. Tour. Manag. 2020, 43, 32-41. [CrossRef]

52. Chuo, H.-Y. Restaurant diners' self-protective behavior in response to an epidemic crisis. Int. J. Hosp. Manag. 2014, 38, 74-83. [CrossRef]

53. Yang, G.-Y.; Lin, X.-L.; Fang, A.-P.; Zhu, H.-L. Eating Habits and Lifestyles during the Initial Stage of COVID-19 Lockdown in China: A Cross-Sectional Study. Nutrients 2021, 13, 970. [CrossRef]

54. Nicola, M.; Alsafi, Z.; Sohrabi, C.; Kerwan, A.; Al-Jabir, A.; Iosifidis, C.; Agha, M.; Agha, R. The socio-economic implications of the coronavirus pandemic (COVID-19): A review. Int. J. Surg. 2020, 78, 185-193. [CrossRef] [PubMed]

55. Baldwin, R.; Weder di Mauro, B. (Eds.) Mitigating the COVID Economic Crisis: Act Fast and Do Whatever It Takes; VoxEU.org eBook; CEPR Press: London, UK, 2020. Available online: https://voxeu.org/content/mitigating-covid-economic-crisis-act-fast-and-dowhatever-it-takes (accessed on 30 July 2021).

56. COVID-19 Update: Germany to Give Easier Access to State-Funded Short-Time Working Allowance. JD Supra. 19 March 2020. Available online: https:/ / www.jdsupra.com/legalnews/covid-19-update-germany-to-give-easier-36702 (accessed on 30 July 2021). 
57. Keogh-Brown, M.R.; Wren-Lewis, S.; Edmunds, W.J.; Beutels, P.; Smith, R.D. The possible macroeconomic impact on the UK of an influenza pandemic. Health Econ. 2010, 19, 1345-1360. [CrossRef]

58. Fanelli, R.M. Changes in the Food-Related Behaviour of Italian Consumers during the COVID-19 Pandemic. Foods 2021, 10, 169. [CrossRef] [PubMed]

59. Ammar, A.; Brach, M.; Trabelsi, K.; Chtourou, H.; Boukhris, O.; Masmoudi, L.; Bouaziz, B.; Bentlage, E.; How, D.; Ahmed, M.; et al. Effects of COVID-19 Home Confinementon Eating Behaviour and Physical Activity: Results of the ECLB-COVID 19 International Online Survey. Nutrients 2020, 12, 1583. [CrossRef]

60. López-Moreno, M.; López, M.T.I.; Miguel, M.; Garcés-Rimón, M. Physical and Psychological Effects Related to Food Habits and Lifestyle Changes Derived from Covid-19 Home Confinement in the Spanish Population. Nutrients 2020, 12, 3445. [CrossRef] [PubMed]

61. Di Renzo, L.; Gualtieri, P.; Pivari, F.; Soldati, L.; Attinà, A.; Cinelli, G.; Leggeri, C.; Caparello, G.; Barrea, L.; Scerbo, F.; et al. Eating habits and lifestyle changes during COVID-19 lockdown: An Italian survey. J. Transl. Med. 2020, 18, 229. [CrossRef]

62. Ruiz-Roso, M.B.; de Carvalho Padilha, P.; Mantilla-Escalante, D.C.; Ulloa, N.; Brun, P.; Acevedo-Correa, D.; Arantes Ferreira Peres, W.; Martorell, M.; Aires, M.T.; de Oliveira Cardoso, L.; et al. Covid-19 Confinement and Changes of Adolescent's Dietary Trends in Italy, Spain, Chile, Colombia and Brazil. Nutrients 2020, 12, 1807. [CrossRef]

63. Celorio-Sardà, R.; Comas-Basté, O.; Latorre-Moratalla, M.L.; Zerón-Rugerio, M.F.; Urpi-Sarda, M.; Illán-Villanueva, M.; FarranCodina, A.; Izquierdo-Pulido, M.; Vidal-Carou, M.D.C. Effect of COVID-19 Lockdown on Dietary Habits and Life-style of Food Science Students and Professionals from Spain. Nutrients 2021, 13, 1494. [CrossRef]

64. Clemente-Suárez, V.J.; Ramos-Campo, D.J.; Mielgo-Ayuso, J.; Dalamitros, A.A.; Nikolaidis, P.A.; Hormeño-Holgado, A.; TorneroAguilera, J.F. Nutrition in the Actual COVID-19 Pandemic. A Narrative Review. Nutrients 2021, 13, 1924. [CrossRef]

65. Del Pozo de la Calle, S.; Alonso Ledesma, I.; Nuñez, O.; Castelló Pastor, A.; Lope Carvajal, V.; Fernández de Larrea Baz, N.; Pérez-Gómez, B.; Pollán, M.; Ruiz Moreno, E. Composition and Nutritional Quality of the Diet in Spanish Households during the First Wave of the COVID-19 Pandemic. Nutrients 2021, 13, 1443. [CrossRef]

66. Detopoulou, P.; Demopoulos, C.A.; Antonopoulou, S. Micronutrients, Phytochemicals and Mediterranean Diet: A Potential Protective Role against COVID-19 through Modulation of PAF Actions and Metabolism. Nutrients 2021, 13, 462. [CrossRef]

67. Kołota, A.; Głabska, D. COVID-19 Pandemic and Remote Education Contributes to Improved Nutritional Behaviors and Increased Screen Time in a Polish Population-Based Sample of Primary School Adolescents: Diet and Activity of Youth during COVID-19 (DAY-19) Study. Nutrients 2021, 13, 1596. [CrossRef] [PubMed]

68. Litton, M.M.; Beavers, A.W. The Relationship between Food Security Status and Fruit and Vegetable Intake during the COVID-19 Pandemic. Nutrients 2021, 13, 712. [CrossRef] [PubMed]

69. Modrzejewska, A.; Czepczor-Bernat, K.; Modrzejewska, J.; Matusik, P. Eating Motives and Other Factors Predicting Emotional Overeating during COVID-19 in a Sample of Polish Adults. Nutrients 2021, 13, 1658. [CrossRef]

70. Monzani, A.; Lionetti, E.; Felici, E.; Fransos, L.; Azzolina, D.; Rabbone, I.; Catassi, C. Adherence to the Gluten-Free Diet during the Lockdown for COVID-19 Pandemic: A Web-Based Survey of Italian Subjects with Celiac Disease. Nutrients 2020, $12,3467$. [CrossRef]

71. Skolmowska, D.; Głąbska, D.; Guzek, D. Differences in Adolescents' Food Habits Checklist (AFHC) Scores before and during Pandemic in a Population-Based Sample: Polish Adolescents' COVID-19 Experience (PLACE-19) Study. Nutrients 2021, 13, 1663. [CrossRef]

72. Mialki, K.; House, L.A.; Mathews, A.E.; Shelnutt, K.P. Covid-19 and College Students: Food Security Status before and after the Onset of a Pandemic. Nutrients 2021, 13, 628. [CrossRef]

73. Ghosal, S.; Sinha, B.; Majumder, M.; Misra, A. Estimation of effects of nationwide lockdown for containing coronavirus infection on worsening of glycosylated haemoglobin and increase in diabetes-related complications: A simulation model using multivariate regression analysis. Diabetes Metab. Syndr. 2020, 14, 319-323. [CrossRef] [PubMed]

74. Moscatelli, F.; Sessa, F.; Valenzano, A.; Polito, R.; Monda, V.; Cibelli, G.; Villano, I.; Pisanelli, D.; Perrella, M.; Daniele, A.; et al. COVID-19: Role of Nutrition and Supplementation. Nutrients 2021, 13, 976. [CrossRef] [PubMed]

75. Czarniecka-Skubina, E.; Górska-Warsewicz, H.; Laskowski, W.; Jeznach, M. Consumer choices and service quality in the university canteens in Warsaw, Poland. Int. J. Environ. Res. Public Health 2019, 16, 3699. [CrossRef]

76. Trafialek, J.; Czarniecka-Skubina, E.; Kulaitiené, J.; Vaitkevičienè, N. Restaurant's Multidimensional Evaluation Concerning Food Quality, Service, and Sustainable Practices: A Cross-National Case Study of Poland and Lithuania. Sustainability 2020, 12, 234. [CrossRef]

77. McNutt, S.; Zimmerman, T.P.; Colaiezzi, B. Computer-assisted dietary assessment methods. In Advanced in the Assessment of Dietary Intake, 1st ed.; CRC Press: Boca Raton, FL, USA, 2017; pp. 45-66. [CrossRef]

78. Ngo, J.; Engelen, A.; Molag, M.; Roesle, J.; Garcia-Segovia, P.; Serra-Majem, L. A review of the use of information and communication technologies for dietary assessment. Br. J. Nutr. 2009, 101, S102-S112. [CrossRef] [PubMed]

79. Eldridge, A.L.; Piernas, C.; Illner, A.-K.; Gibney, M.J.; Gurinović, M.A.; De Vries, J.H.M.; Cade, J.E. Evaluation of New TechnologyBased Tools for Dietary Intake Assessment-An ILSI Europe Dietary Intake and Exposure Task Force Evaluation. Nutrients 2019, 11, 55. [CrossRef]

80. Ostertagová, E.; Ostertag, O.; Kováč, J. Methodology and Application of the Kruskal-Wallis Test. Appl. Mech. Mater. 2014, 611, 115-120. [CrossRef] 
81. Chan, Y.; Walmsley, R.P. Learning and Understanding the Kruskal-Wallis One-Way Analysis-ofVariance-by-Ranks Test for Differences Among Three or More Independent Groups. Phys. Ther. 1997, 77, 1755-1762. [CrossRef]

82. Setyaningsih, S. Using Cluster Analysis Study to Examine the Successful Performance Entrepreneur in Indonesia. Procedia Econ. Financ. 2012, 4, 286-298. [CrossRef]

83. Saxena, A.K.; Prasad, M.; Gupta, A. A Review of Clustering Techniques and Developments. Neurocomputing 2017, $267,664-681$. [CrossRef]

84. Fanelli, R.M. The (un)sustainability of the land use practices and agricultural production in EU countries. Int. J. Environ. Stud. 2019, 76, 273-294. [CrossRef]

85. Fanelli, R.M. A new classification of European Union regions: A decision support tool for policymakers. Span. J. Agric. Res. 2019, 17, e0102. [CrossRef]

86. Stanisz, A. Przystepny kurs Statystyki z Zastosowaniem Statistica Pl na Przykładach z Medycyny. Tom 3. Analizy Wielowymiarowe; Statsoft Poland: Cracow, Poland, 2007.

87. Aczel, A.D. Complete Business Statistics, 8th ed.; Wohl Publishing Inc.: Morristown, NJ, USA, 2012.

88. EFSA. Coronavirus: No Evidence That Food Is a Source or Transmission Route. 2020. Available online: https://www.efsa.europa. eu/en/news/coronavirus-no-evidence-food-source-or-transmission-route (accessed on 17 May 2021).

89. Główny Inspektorat Sanitarny. COVID-19 i Bezpieczeństwo Żywności-Wytyczne dla Przedsiębiorstw Sektora SpożywczegoWytyczne Tymczasowe. Available online: https://www.gov.pl/web/gis/covid-19-i-bezpieczenstwo-zywnosci-wytyczne-dlaprzedsiebiorstw-sektora-spozywczego,WHO_2019_nCoV_Food_Safety_20201-pol-2.pdf (accessed on 17 May 2021).

90. European Commission, Directorate-General for Health and Food Safety. COVID-19 and Food Safety, Questions and Answers; Crisis Management in Food, Animals and Plants: Food Hygiene; European Commission Publisher: Brussels, Belgium, 2020. Available online: https:/ / ec.europa.eu/food/sites/food/files/safety/docs/biosafety_crisis_covid19_qandas_en.pdf (accessed on 5 May 2021).

91. WHO. COVID-19 and Food Safety: Guidance for Food Businesses: Interim Guidance. 2020. Available online: https://www.who. $\mathrm{int} /$ publications/i/item/covid-19-and-food-safety-guidance-for-food-businesses (accessed on 20 May 2021).

92. Centers for Disease Control and Prevention (CDC). Food Safety and Coronavirus Disease 2019 (COVID-19). 2020. Available online: https: / / www.cdc.gov/foodsafety/newsletter/food-safety-and-Coronavirus.html (accessed on 10 May 2021).

93. Raj, M.; Sundararajan, A.; You, C. COVID-19 and Digital Resilience: Evidence from Uber Eats. arXiv 2020, arXiv:2006.07204.

94. Stewart, H.; Blisard, N.; Bhuyan, S.; Nayga, R. The Demand for Food Away from Home: Full-Service or Fast Food? United States Department of Agriculture, Economic Research Service. 2004. Available online: https: / /www.ers.usda.gov/webdocs/ publications /41619/15272_aer829_1_pdf?v=38.3 (accessed on 28 May 2021).

95. Alonso, A.D.; Kok, S.K.; Bressan, A.; O’Shea, M.; Sakellarios, N.; Koresis, A.; Buitrago Solis, M.A.; Santoni, L.J. COVID-19, aftermath, impacts, and hospitality firms: An international perspective. Int. J. Hosp. Manag. 2020, 91, 102654. [CrossRef]

96. Kim, J.; Lee, J.C. Effects of COVID-19 on preferences for private dining facilities in restaurants. J. Hosp. Tour. Manag. 2020, 45, 67-70. [CrossRef]

97. Baum, T.; Mooney, S.K.; Robinson, R.N.; Solnet, D. COVID-19's impact on the hospitality workforce-new crisis or amplification of the norm? Int. J. Contemp. Hosp. Manag. 2020, 32, 2813-2829. [CrossRef]

98. Sigala, M. Tourism and COVID-19: Impacts and implications for advancing and resetting industry and research. J. Bus. Res. 2020, 117, 312-321. [CrossRef]

99. Liddle, A.J. An Early Look at the Impact of Coronavirus on Restaurant Sales. Nation's Restaurant News. 21 April 2020. Available online: https:/ / www.nrn.com/fast-casual/early-look-impact-coronavirus-restaurant-sales (accessed on 18 May 2021).

100. Covid-19 Impacts. Afr. Res. Bull. 2020, 57, 22951. [CrossRef]

101. Galanakis, C.M. The food systems in the era of the Coronavirus (COVID_19) pandemic crisis. Foods 2020, 9, 523. [CrossRef]

102. Hailu, G. Economic thoughts on COVID-19 for Canadian food processors. Can. J. Agric. Econ. 2020, 68, 163-169. [CrossRef]

103. International Labor Organization (ILO). The Six-Step COVID-19 Business Continuity Plan. 2020. Available online: https: //www.ilo.org/actemp/publications/WCMS_740375/lang--en/index.htm (accessed on 10 May 2021).

104. McEwan, K.; Marchand, L.; Shang, M.; Bucknell, D. Potential implications of COVID-19 on the Canadian pork industry. Can. J. Agric. Econ. 2020, 68, 201-206. [CrossRef]

105. Weersink, A.; von Massow, M.; McDougall, B. Economic thoughts of the potential implications of COVID-19 on the Canadian dair and poultry sectors. Can. J. Agric. Econ. 2020, 68, 195-200. [CrossRef]

106. Van Doremalen, N.; Bushmaker, T.; Morris, D.H.; Holbrook, M.G.; Gamble, A.; Williamson, B.N.; Tamin, A.; Harcourt, J.L.; Thornburg, N.J.; Gerber, S.I.; et al. Aerosol and surface stability of SARS-CoV-2 as compared with SARS-CoV-1. N. Engl. J. Med. 2020, 382, 16. [CrossRef] [PubMed]

107. Yannas, F. FDA's Perspective on Food Safety and Availability during and beyond COVID-19. 2020. Available online: https: / / www.fda.gov / food/conversations-experts-food-topics/fdas-perspective-food-safety-and-availability-during-andbeyond-covid-19 (accessed on 5 May 2021).

108. OSHA. Guidance on Preparing Workplaces for COVID-19. Occupational Safety and Health Administration. 2020. Available online: https:/ / www.osha.gov/Publications/OSHA3990.pdf (accessed on 10 May 2021).

109. Ozili, P.K.; Arun, T. Spillover of COVID-19: Impact on the Global Economy. 2020. Available online: https://papers.ssrn.com/sol3 / papers.cfm?abstract_id=3562570 (accessed on 28 May 2021). 
110. Elitzak, H.; Okrent, A. New U.S. Food Expenditure Estimates Find Food-Awayfrom-Home Spending Is Higher Than Previous Estimates. 2018. Available online: https://www.ers.usda.gov/amber-waves/2018/november/new-u-s-food-expenditureestimates-find-food-away-from-homespending-is-higher-than-previous-estimates (accessed on 1 August 2021).

111. Lee, K.; Caine-Bish, N. Understanding Restaurant Healthfulness in Food Deserts. J. Nutr. Educ. Behav. 2021, 53, 511-516. [CrossRef] [PubMed]

112. Silva, M.N.; Gregório, M.J.; Santos, R.; Marques, A.; Rodrigues, B.; Godinho, C.; Silva, C.S.; Mendes, R.; Graça, P.; Arriaga, M.; et al. Towards an In-Depth Understanding of Physical Activity and Eating Behaviours during COVID-19 Social Confinement: A Combined Approach from a Portuguese National Survey. Nutrients 2021, 13, 2685. [CrossRef]

113. Pujia, R.; Ferro, Y.; Maurotti, S.; Khoory, J.; Gazzaruso, C.; Pujia, A.; Montalcini, T.; Mazza, E. The Effects of COVID-19 on the Eating Habits of Children and Adolescents in Italy: A Pilot Survey Study. Nutrients 2021, 13, 2641. [CrossRef]

114. Sánchez-Sánchez, E.; Díaz-Jimenez, J.; Rosety, I.; Alférez, M.J.M.; Díaz, A.J.; Rosety, M.A.; Ordonez, F.J.; Rosety-Rodriguez, M. Perceived Stress and Increased Food Consumption during the 'ThirdWave' of the COVID-19 Pandemic in Spain. Nutrients 2021, 13, 2380. [CrossRef]

115. Rodriguez-Leyva, D.; Pierce, G.N. The Impact of Nutrition on the COVID-19 Pandemic and the Impact of the COVID-19 Pandemic on Nutrition. Nutrients 2021, 13, 1752. [CrossRef]

116. Niles, M.T.; Bertmann, F.; Belarmino, E.H.; Wentworth, T.; Biehl, E.; Neff, R. The Early Food Insecurity Impacts of COVID-19. Nutrients 2020, 12, 2096. [CrossRef]

117. Adams, E.L.; Caccavale, L.J.; Smith, D.; Bean, M.K. Food Insecurity, the Home Food Environment, and Parent Feeding Practices in the Era of COVID-19. Obesity 2020, 28, 2056-2063. [CrossRef] [PubMed]

118. Bin Zarah, A.; Enriquez-Marulanda, J.; Andrade, J.M. Relationship between Dietary Habits, Food Attitudes and Food Security Status among Adults Living within the United States Three Months Post-Mandated Quarantine: A Cross-Sectional Study. Nutrients 2020, 12, 3468. [CrossRef]

119. Skotnicka, M.; Karwowska, K.; Kłobukowski, F.; Wasilewska, E.; Małgorzewicz, S. Dietary Habits before and during the COVID-19 Epidemic in Selected European Countries. Nutrients 2021, 13, 1690. [CrossRef] [PubMed] 